\title{
Stem cells and their potential as cardiac therapeutics
}

\author{
Radiana D. Antarianto
}

\begin{abstract}
Abstrak
Sel induk(Stem Cell) adalah sel pembangun setiap organ dan jaringan tubuh kita. Dia adalah sel yang belum berdiferensiasi, tapi dengan kondisi tepat mampu berkembang menjadi jaringan khusus dan organ tertentu. Sebagian besar dari sel-sel jaringan tidak dapat beregenerasi jika rusak berat atau sakit, seperti pada kasus Infark Miokard. Penelitian terbaru mulai berfokus pada sel induk, yang dapat berproliferasi, dan berdiferensiasi menjadi sel otot jantung. Artikel ini bertujuan untuk menerangkan transplantasi sel induk pada infark miokard, kemajuan dan kendala yang terdapat dalam bidang kardiomioplasti selular. (Med J Indones 2005; 15:3-8)
\end{abstract}

\begin{abstract}
Stem cells are the foundation cells for every organ and tissue in the body. They are undifferentiated cells that under proper conditions begin to develop into specialized tissues and organs. Most of the body's specialized cells cannot be replaced by natural processes if they are seriously damaged or diseased, such as in Myocardial Infarction. Recent interest has focused on stem cells, which can proliferate, and differentiate into cardiomyocytes.This paper aim to provide overview of stem cell transplantation in myocardial infarction, milestones and setbacks in the study of cellular cardiomyoplasty. (Med J Indones 2005; 15:3-8)
\end{abstract}

Keywords: Stem cell, myocardial infarction, cellular cardiomyoplasty

The last 5 years there's an explosion of new reports on human stem cells.Stem cells are the foundation cells for every organ, tissue and cell in the body. They are undifferentiated cells that under proper conditions begin to develop into specialized tissues and organs. Additionally, stem cells are self-sustaining and can replicate themselves for long periods of time. Most of the body's specialized cells cannot be replaced by natural processes if they are seriously damaged or diseased. Stem cells can be used to generate healthy and functioning specialized cells, which can then replace diseased or dysfunctional cells. The process is called cell therapy. Some conditions or injuries can be treated through transplantation of entire healthy organs, but there is a shortage of donors. Stem cells can serve as an alternate and renewable source for specialized cells and tissues. ${ }^{1,2}$

Department of Histology, Faculty of Medicine, University of Indonesia, Jakarta, Indonesia
Myocardial infarction is the leading cause of congestive heart failure and death in the industrialized world. Current therapy is limited in preventing the progression of ventricular remodeling and congestive heart failure. Recent interest has focused on stem cells, which can proliferate, and differentiate into cardiomyocytes. Myocardial regeneration with stemcell transplantation is a possible treatment option to reverse the deleterious hemodynamic and neurohormonal effects that occur after myocardial infarction and can lead to congestive heart failure. ${ }^{3}$

This paper aim to provide overview of stem cell transplantation in myocardial infarction, milestones and setbacks in the study of cellular cardiomyoplasty.

\section{CELLULAR CARDIOMYOPLASTY}

The adult heart contains a subpopulation of cardiomyocytes that are not terminally differentiated and reenter the cell cycle and undergo nuclear mitotic division soon after myocardial infarction. ${ }^{4}$ In other words, myocardium does not substantially regenerate after myocardial infarction. Loss of cardiomyocytes 
after myocardial infarction (MI), combined with the absence of endogenous repair mechanisms, is a causative factor in progression to heart failure. A pathologic ventricular remodeling ensues as damaged myocardium is replaced by a fibrous scar composed of extracellular matrix produced by nonmyocytic cells, resulting in ventricular function loss. ${ }^{1,3}$

In an effort to replace cardiomyocytes lost after ischemia, cellular transplantation has been investigated as a potential therapy for MI termed cellular cardiomyoplasty, the approach has gone from an interesting research novelty to clinical reality. Cellular cardiomyoplasty, may be attained in one of the following ways: 1) by transplanting stem cells that differentiate into cardiomyocytes or promote angiogenesis; 2) by mobilizing bone marrow resident stem cells to the site of injury with the use of cytokines, such as granulocyte colony-stimulating factor and stem-cell factor; or 3) by administering local treatment with growth factors, such as insulin-like and hepatocyte growth factors, that induce the differentiation of cardiac progenitor cells into cardiomyocytes. ${ }^{1,3}$

Transplanted stem cells undergo a "homing" process in which they are attracted to the site of injury. The exact homing mechanism and organ-specific differentiation signals for stem cells are not clearly understood but may be related to microenvironmental factors that are favorable to stem-cell growth and function, integrin and other adhesion molecules, homing receptors, ischemia, and increased expression of vascular endothelial growth factor. ${ }^{3}$

Another strategy for cellular cardiomyoplasty involves an indirect approach. Bone marrow stem cells, which were mobilized by systemic injections of cytokines (such as granulocyte colony-stimulating factor and stem-cell factor) homed to the infarcted myocardium, replicated, differentiated, promoted myocardial repair, and improved cardiac function in a murine model. ${ }^{3}$

A less common strategy for cellular cardiomyoplasty is the use of growth factors, such as insulin-like and hepatocyte growth factors, to attract cardiac progenitor cells, induce the differentiation of cardiac progenitor cells into cardiomyocytes, and promote cardiomyocyte replication. Insulin-like growth factor also protects against cardiomyocyte death and attenuates left ventricular remodeling in a mouse model. ${ }^{5}$

\section{OVERVIEW OF CELLULAR CARDIOMYOPLASTY STUDIES}

\section{Cellular Cardiomyoplasty in Animal Models}

Soonpaa and colleagues demonstrated that transplanted fetal cardiomyocytes could survive, proliferate, and form nascent intercalated disks with host myocardium in murine models. 6 Transplanting fetal cardiomyocytes into a myocardial scar formed new cardiac tissue and improved cardiac function.

In another study, Etzion and colleagues reported attenuation of ventricular dilatation, infarct thinning, and cardiac dysfunction after embryonic cardiomyocytes were transplanted into rat hearts after myocardial infarction. ${ }^{7}$ Fetal cardiomyocytes may also contribute to the release of cardioprotective factors, such as vascular endothelial growth factor, through a paracrine effect that stimulates nascent blood vessel formation in grafted areas and host ventricle. Increased microcirculation provides the transplanted cells not only with increased perfusion but may also be a means to remove necrotic debris from myocardial infarction.

Jain and colleagues showed that implantation of skeletal myoblasts formed viable myoblast implants and attenuated ventricular dilatation, thereby improving exercise capacity, cardiac function, and left ventricular systolic pressures after myocardial infarction in a rat model. ${ }^{8}$ Similarly, transplanting autologous skeletal myoblasts in an infarcted area minimized left ventricular dysfunction and improved systolic function in the scarred myocardium through colonization of fibrosis by skeletal muscle cells with the expression of myosin heavy chain after myocardial infarction in a sheep model for up to 1 year. ${ }^{9}$ The degree of improvement of cardiac function is related to the number of myoblasts injected. The potential for intravascular delivery of skeletal myoblasts also makes these cells particularly appealing as the donor cell of choice.

The intravenous administration of ex vivo expanded endothelial progenitor cells enhanced neovascularization, reduced left ventricular dilatation, and preserved cardiac function after myocardial infarction in a rat model. $^{10}$

Kocher and colleagues intravenously administered granulocyte colony-stimulating factor-mobilized, human bone marrow-derived endothelial progenitor cells that 
migrated into the infarcted region within 48 hours, transdifferentiated into endothelial cells, induced neovascularization, limited apoptosis of the hypertrophied cardiomyocytes in the peri-infarct area and ventricular remodeling, and improved cardiac function after myocardial infarction in a rat model. ${ }^{11}$

In a rat model, intramyocardial injection of embryonic stem cells engrafted in the myocardium and improved cardiac function and myocardial contractility after myocardial infarction. ${ }^{12}$

Implanting autologous or allogenic swine mesenchymal stem cells after myocardial infarction sustained engraftment in host myocardium, differentiated into cardiomyocytes, maintained wall thickness, reduced ventricular remodeling, and improved cardiac function. ${ }^{13}$ In another study, Min and colleagues reported improvement in cardiac function and resting blood flow in infarcted myocardium with intramyocardial transplantation of human mesenchymal stem cells and a statistically significantly greater improvement in cardiac function and resting blood flow with cotransplantation of human fetal cardiomyocytes after myocardial infarction in a porcine model. ${ }^{14}$

Mesenchymal stem cells injected with fresh bone marrow into infarcted myocardium induced the overexpression of cardiac tenascin and sympathetic nerve sprouting, resulting in myocardial sympathetic hyperinnervation in swine. The tenascin gene family of extracellular matrix proteins is implicated in nerve regeneration, cardiac remodeling, vascular remodeling, and neo-intimal proliferation. This mechanism may explain improved myocardial function after mesenchymal cell transplantation. However, sympathetic hyperinnervation may lead to life-threatening ventricular tachyarrhythmias. ${ }^{15,16}$

Treatment with 5-azacytidine (a DNA-demethylating agent) of adult mesenchymal stem cells from abdominal subcutaneous fatty tissue induced direct differentiation into cardiomyocytes in a rabbit model. Similarly, Tomita and colleagues reported that bone marrow cells cultured with 5-azacytidine differentiated into cardiac-like cells before injection and in vivo in myocardial infarction and improved cardiac function. Pretreating autologous mesenchymal stem cells with 5 -azacytidine before transplantation into infarcted myocardium may increase the likelihood of successful regeneration of infarcted myocardium. ${ }^{17}$
Orlic and colleagues isolated bone marrow stem cells and directly injected them in the margin bordering the infarct of the left ventricle of mice. ${ }^{19}$ These cells migrated into the region bordering the infarction and differentiated into cardiomyocytes and endothelial cells, generating de novo myocardium, improving cardiac function, and leading to neovascularization. Direct intramyocardial injection may require fewer cells to achieve engraftment compared with intracoronary or intravenous administration. Although the injection process is simple and can be performed by direct inspection of the potential target zones, this invasive delivery in the form of cardiac surgery is associated with intraoperative and postoperative risks and had a success rate of $40 \%$ in 1 study in a mouse model.

\section{Phase I Clinical Studies: Human Trials}

Thus far, human studies on stem-cell transplantation have been small and nonrandomized. We discuss the clinical studies that have been conducted with stemcell transplantation :

1. Strauer et al infused bone marrow-derived mononuclear cells into the infarct-related artery by percutaneous transluminal coronary angioplasty. The cells were isolated by Ficoll gradient centrifugation and cultivated overnight. ${ }^{19}$ Bone marrow-derived mononuclear cells (mean 2.8x107) were infused 5 to 9 days after the acute myocardial infarction. In comparison to 10 nonrandomized control patients, who did not undergo cell therapy or additional catheterization, bone marrow-derived mononuclear cell infusion enhanced regional infarct region perfusion as assessed by thallium scintigraphy. Moreover, stroke volume, end-systolic volume, myocardial perfusion of the infarct region and contractility indices were improved after cell therapy. ${ }^{4,3}$

2. In the Transplantation of Progenitor Cells and Regeneration Enhancement in Acute Myocardial Infarction (TOPCARE-AMI) trial, patients were selected to receive either bone marrow-derived mononuclear cells or endothelial progenitor cells. ${ }^{20}$ Bone marrow-derived mononuclear cells (50 $\mathrm{mL}$ aspirate) were isolated by Ficoll gradient centrifugation and immediately infused after preparation. Endothelial progenitor cells were ex vivo expanded out of peripheral blood mononuclear cells from $250 \mathrm{~mL}$ blood for 3 days. Bone marrow cells or endothelial progenitor cells were infused a mean of 4 days after myocardial 
infarction. Bone marrow cells and endothelial progenitor cells significantly improved the global ejection fraction, as assessed by left ventricular angiography, compared with a nonrandomized control patient collective. Functional improvement was confirmed by MRI in a patient subcollective. Cell therapy also increased coronary flow reserve, which indicates an enhancement of neovascularization. Endothelial progenitor cells and bone marrow cells showed similar effects in vivo.

3. Intramuscular injection of bone marrow-derived stem/progenitor cells was used as the route of application in 4 additional pilot trials. Direct injection of isolated hematopoietic stem cells, which express AC133+ (1 to 1.6x106 cells), was performed during bypass surgery in 6 patients. Three other studies injected bone marrow-derived mononuclear cells by catheter-based transendocardial delivery. Perin et al and Tse et al used the NOGA catheter. Injection was guided by electromechanical mapping. Perin et al showed a significant improvement of ejection fraction and end-systolic volume in 14 patients with chronic ischemic heart failure who were treated with bone marrow-derived mononuclear cells compared with 7 controls. Perfusion was determined by single-photon emission CT and was significantly improved in patients treated with bone marrowderived mononuclear cells. Tse et al treated 8 patients with ischemic heart disease and reported improvement of wall motion and wall thickening as well as decreased hypoperfusion 90 days after cell therapy. ${ }^{3}$

4. Fuchs and coworkers tested the effect of total unfractionated total bone marrow in 10 no-option patients with advanced coronary artery disease. Canadian Cardiovascular Society angina score and stress-induced ischemia were significantly improved after 3-month follow-up. ${ }^{3}$

5. Hamano and colleagues locally injected autologous bone marrow cells into areas of ischemic myocardium during coronary artery bypass grafting in 5 patients.$^{21}$ Perfusion increased in the treated area of the myocardium in 3 patients. Coronary angiography also demonstrated the formation of new collateral blood vessels at this site.

Furthermore, a first randomized trial was recently presented. In this study, 60 patients with acute myocardial infarction were randomized to receive intracoronary infusion of bone marrow-derived mononuclear cells or were not treated (no recatheterization, no placebo). The authors reported an increase in ejection fraction and a reduction of end-systolic volumes as assessed by MRI in the group of patients receiving bone marrow cells.

All studies at present are limited by the small patient collective and by the design of pilot safety and feasibility studies, which precludes a randomized, placebo-controlled, double-blind design. However, increased perfusion was demonstrated in most of the studies. $^{3}$

\section{TRACING THE TRANSPLANTED STEM CELLS}

The fate of transplanted stem cells in animal models has been mainly assessed postmortem by histologic analysis. Noninvasive in vivo imaging techniques are needed in upcoming clinical trials to monitor and detail donor cell delivery, myocardial differentiation, integration into the damaged myocardium, and contribution to cardiac function. Delivery of mesenchymal stem cells with radiograph fluoroscopy is limited because of the inability to verify whether the injection was successful. Cardiac MRI successfully detected and tracked intramyocardial injection of magnetically labeled mesenchymal stem cells after myocardial infarction in a swine model. Similar results were obtained with targeted catheter-based implantation of iron-loaded myogenic precursor cells into infarcted myocardium in a swine model. Cardiac MRI allows the accurate noninvasive in vivo assessment of the size and location of the intramyocardial injection, thus providing information on the extent of stem-cell retention. Magnetic resonance imaging can also be used to guide catheter-based cardiac injections. Percutaneous endomyocardial drug delivery was conducted with real-time MRI and allowed for precise 3-dimensional localization of injections in the left ventricular wall in swine. ${ }^{22}$

Human endothelial progenitor cells were radioactively labeled with 111-indium oxine, a safe and commercially available radioactive tracer for monitoring blood cells for inflammation scintigraphy, and were administered by intravenous and left ventricular intracavitary route for the in vivo monitoring of their fate after myocardial infarction in a rat model. Scintigraphic images obtained after injection of 111-indium oxinelabeled endothelial progenitor cells demonstrated increased homing of transplanted cells and tracer uptake in the heart after myocardial infarction. ${ }^{23}$ This 
suggests that radiolabeling with 111-indium oxine is a potential technique to noninvasively monitor transplanted endothelial progenitor cells and assess the fate and tissue distribution of these cells in the myocardium after myocardial infarction in clinical practice.

\section{SETBACKS IN CELLULAR CARDIOMYOPLASTY: PROBLEMS TO SOLVE}

Safety is always a major concern in dealing with clinical trials involving stem cells. Implanted stem cells may differentiate into fibroblasts rather than myocytes. This may enhance scar formation, further depressing myocardial function and creating a substrate for lifethreatening arrhythmias. ${ }^{24}$ There may also be lifethreatening consequences if stem cells incompletely integrate into the myocardium and adversely affect electrical conduction and syncytial contraction of the heart . Tumor formation associated with embryonic stem cells, such as teratomas, may also occur. ${ }^{3}$

Late-onset toxicity may occur from using whole populations of bone marrow mononuclear cells, which contain different organ-specific stem cells. These nonessential cells may incorporate into regenerating myocardium, resulting in the generation of noncardiac tissues. ${ }^{3}$

\section{CONCLUSIONS}

Stem-cell transplantation in acute myocardial infarction is still in its infancy. Preliminary data from animal models suggest that infarcted myocardium can be regenerated by implanting stem cells. Whether stem-cell transplantation offers a sustained clinical benefit by reversing ventricular remodeling in myocardial infarction is unknown, given that too few patients have undergone stem-cell transplantation to derive any meaningful efficacy and safety data. However, larger double-blinded, controlled studies with therapeutic end points are imperative to clarify the role of stem-cell transplantation for myocardial regeneration.

\section{REFERENCES}

1. Pittenger MF, Martin BJ. Mesenchymal Stem Cells and their potential as Cardiac therapeutics. Circ Res 2004; 95:9-20.

2. Losordo DW, Dimmeter S. Therapeutic Angiogenesis and Vasculogenesis for Ischemic Disease Part II Cell Based Therapies. Circulation 2004;109:2692-7.
3. Lee MS, Makkar RR. Stem Cell Transplantation in Myocardial Infarction A Status Report. Ann Intern Med 2004;140:729-37.

4. Beltrami AP, Urbanek K, Kajstura J, Yan SM, Finato N, Bussani R, et al. Evidence that human cardiac myocytes divide after myocardial infarction. $\mathrm{N}$ Engl $\mathrm{J}$ Med 2001;344:1750-7.

5. Welch S, Plank D, Witt S, Glascock B, Schaefer E, Chimenti S, et al. Cardiac-specific IGF-1 expression attenuates dilated cardiomyopathy in tropomodulinoverexpressing transgenic mice. Circ Res 2002;90:641-8.

6. Soonpaa MH, Koh GY, Klug MG, Field LJ. Formation of nascent intercalated disks between grafted fetal cardiomyocytes and host myocardium. Science 1994; 264:98-101

7. Etzion S, Battler A, Barbash IM, Cagnano E, Zarin P, Granot Y, et al. Influence of embryonic cardiomyocyte transplantation on the progression of heart failure in a rat model of extensive myocardial infarction. J Mol Cell Cardiol 2001;33:1321-30.

8. Jain M, DerSimonian H, Brenner DA, Ngoy S, Teller P, Edge AS, et al. Cell therapy attenuates deleterious ventricular remodeling and improves cardiac performance after myocardial infarction. Circulation 2001;103:1920-7.

9. Ghostine S, Carrion C, Souza LC, Richard P, Bruneval P, Vilquin JT, et al. Long-term efficacy of myoblast transplantation on regional structure and function after myocardial infarction. Circulation 2002;106:131-6.

10. Kawamoto A, Gwon HC, Iwaguro H, Yamaguchi JI, Uchida S, Masuda $\mathrm{H}$, et al. Therapeutic potential of ex vivo expanded endothelial progenitor cells for myocardial ischemia. Circulation 2001;103:634-7.

11. Kocher AA, Schuster MD, Szabolcs MJ, Takuma S, Burkhoff D, Wang J, et al. Neovascularization of ischemic myocardium by human bone-marrow-derived angioblasts prevents cardiomyocyte apoptosis, reduces remodeling and improves cardiac function. Nat Med 2001;7:430-6.

12. Min JY, Yang Y, Converso KL, Liu L, Huang Q, Morgan JP, et al. Transplantation of embryonic stem cells improves cardiac function in postinfarcted rats. J Appl Physiol 2002;92:288-96.

13. Shake JG, Gruber PJ, Baumgartner WA, Senechal G, Meyers J, Redmond JM, et al. Mesenchymal stem cell implantation in a swine myocardial infarct model: engraftment and functional effects. Ann Thorac Surg 2002;73:1919-25; discussion 1926.

14. Min JY, Sullivan MF, Yang Y, Zhang JP, Converso KL, Morgan JP, et al. Significant improvement of heart function by cotransplantation of human mesenchymal stem cells and fetal cardiomyocytes in postinfarcted pigs. Ann Thorac Surg 2002;74:1568-75.

15. Cao JM, Fishbein MC, Han JB, Lai WW, Lai AC, Wu TJ, et al. Relationship between regional cardiac hyperinnervation and ventricular arrhythmia. Circulation 2000; 101:1960-9.

16. Cao JM, Chen LS, KenKnight BH, Ohara T, Lee MH, Tsai J, et al. Nerve sprouting and sudden cardiac death. Circ Res 2000;86:816-21.

17. Tomita S, Li RK, Weisel RD, Mickle DA, Kim EJ, Sakai $\mathrm{T}$, et al. Autologous transplantation of bone marrow cells improves damaged heart function. Circulation 1999; 100:247-56. 
18. Orlic D, Kajstura J, Chimenti S, Jakoniuk I, Anderson $\mathrm{SM}, \mathrm{Li} \mathrm{B}$, et al. Bone marrow cells regenerate infarcted myocardium. Nature 2001;410:701-5.

19. Strauer BE, Brehm M, Zeus T, Kostering M, Hernandez A, Sorg RV, et al. Repair of infarcted myocardium by autologous intracoronary mononuclear bone marrow cell transplantation in humans. Circulation 2002;106:1913-8.

20. Assmus B, Schachinger V, Teupe C, Britten M, Lehmann $\mathrm{R}$, Döbert N, et al. Transplantation of Progenitor Cells and Regeneration Enhancement in Acute Myocardial Infarction (TOPCARE-AMI). Circulation 2002; 106:3009-17.

21. Hamano K, Nishida M, Hirata K, Mikamo A, Li TS, Harada M, et al. Local implantation of autologous bone marrow cells for therapeutic angiogenesis in patients with ischemic heart disease: clinical trial and preliminary results. Jpn Circ J 2001;65:845-7.

22. Kraitchman DL, Heldman AW, Atalar E, Amado LC, Martin BJ, Pittenger MF, et al. In vivo magnetic resonance imaging of mesenchymal stem cells in myocardial infarction. Circulation 2003;107:2290-3.

23. Aicher A, Brenner W, Zuhayra M, Badorff C, Massoudi $\mathrm{S}$, Assmus B, et al. Assessment of the tissue distribution of transplanted human endothelial progenitor cells by radioactive labeling. Circulation 2003;107:2134-9.

24. Zhang YM, Hartzell C, Narlow M, Dudley SC Jr. Stem cell-derived cardiomyocytes demonstrate arrhythmic potential. Circulation 2002;106:1294-9. 